\title{
28 Research Suare \\ Bisphenol A Acts As Developmental Agonist in Culex Quinquefasciatus Say
}

\author{
Ayana Gayathri \\ University College Thiruvananthapuram \\ Evans DA ( $\nabla$ drevansda@gmail.com ) \\ University of Kerala https://orcid.org/0000-0002-9121-3735
}

\section{Research Article}

Keywords: Bisphenol A, Developmental agonist, Ecdysone receptor EcRA, Ecdysone inducible gene E75A, 20-hydroxy ecdysone, Phospholipase A2, Culex quinquefasciatus.

Posted Date: April 26th, 2021

DOI: https://doi.org/10.21203/rs.3.rs-401763/v1

License: (c) (i) This work is licensed under a Creative Commons Attribution 4.0 International License. Read Full License 


\section{Abstract}

Plastic - derived Bisphenol A (BPA) contaminated sewages in Trivandrum, Kerala, India are mosquito breeding sites. After summer rain, BPA in the stagnant water samples ranged between 0.86 and $1.14 \mathrm{ppm}$. $1.0 \mathrm{ppm}$ BPA is considered as environmentally relevant concentration. Present study revealed that BPA is a developmental agonist of Culex quinquefasciatus. Embryonic and larval development are shortened by BPA but pupal development is unaffected. Under the atmospheric temperature of 26 to $31^{\circ} \mathrm{C}$ lifecycle was completed within 312 hours but during summer it was completed within 278 hours, meanwhile atmospheric temperature ranged between 30 and $37^{\circ} \mathrm{C}$. Reduction in the duration of development due to BPA was 50 to 70 hours during summer and 60 to 80 hours in other seasons. Larval - pupal stadium of the mosquito has three surges of 20-hydroxy ecdysone(20-HE), at 24,32 and 48th hour of the 4th instar. BPA resulted dose-dependent advancement of 20-HE peaks, Phospholipase $\mathrm{A}_{2}$ induction and expression of Ecdysone receptor EcRA and Ecdysone inducible gene E75A, which culminated in early pupation. Adults emerging from 1.0 ppm BPA treatment did not show significant difference in sanguivory and fecundity compared to control but pupae developed in 2 and 4 ppm BPA were significantly small.

\section{Introduction}

Accumulation of plastic wastes in sewage and formation of mosquito breeding sites are a major cause of vector borne diseases in urban areas. Studies on mosquito larval index of Thiruvananthapuram city, Kerala, India show swarms of mosquitoes after summer rain, especially Aedes albopictus in accumulated water in plastic wastes and Culex quinquefasciatus in such water with abundance of organic material (Sunilkumar et al. 2018). Coconut shells traditionally used in rubber plantations of Kerala to collect the tapped latex form breeding sites of A. albopictus during rainy season (Sumodan 2003). These are now completely replaced by plastic cups. Bisphenol A (BPA) is a bioactive compound released from plastic wastes (Yamamoto and Yasuhara 1999) and hence mosquito larvae developed in these sites have ample chances of being exposed to this compound.

BPA is a well known xenoestrogen which causes endocrine disruption in fishes leading to expression of vitellogenin gene and oocyte development in testis (Yokota et al. 2000 ; Virk et al. 2014 ) and it interferes in metamorphosis of amphibian tadpoles (Fx Yang et al. 2005). Studies have shown that BPA also causes developmental abnormalities in invertebrates such as crustaceans (Biggers and Lanfer 2004) molluscs (Fabbri et al. 2014) and in insects (Watts et al. 2003). In Drosophila melanogaster, BPA caused delay on larval development and pupation time (Alti and Ulnu 2012). In a transgeneration study, $D$. ananassea reared in culture medium having high doses of BPA for five generations do not cause any developmental arrest but there was protraction of life cycle by 7 to 9 hours. However, at higher doses of 10,15 and $20 \mathrm{mg} / \mathrm{L}$, adult flies have shown abnormal phenotypic characters on the antennae (Anuji et al. 2018). Eventhough vector control measures coupled with scientific research are adopted against mosquitoes, many urban and rural areas fail to effectively manage the twin problems such as vector borne diseases and plastic waste disposal. Rather than providing physical amenities to mosquito development residues of plastics may unravel a chemical environment through releasing a suite of 
bioactive molecules including BPA in the breeding sites. So the present study was undertaken to understand the effect of BPA on the developmental stages and metamorphosis in Culex quinquefasciatus.

\section{Materials And Methods}

\section{Estimation of Bisphenol A in mosquito breeding sites}

Water samples (one litre) from four breeding sites with huge deposits of disposable plastics were collected in amber coloured bottles. BPA was quantitatively estimated by Gas chromatography - Mass spectroscopy with instrument Varian CP 3800 connected to MS model Saturn 2200.The capillary column with phenyl siloxane as packing material (Varian, USA) and the carrier gas used was chlorated helium. Ionisation mass of the mass spectrometer $70 \mathrm{eV}$. The detector was operated in positive ion mode using selected ion monitoring and peak obtained at retention time was analysed by Mass spectrum detector. The peaks detected were $\mathrm{m} / \mathrm{z} 228\left(\mathrm{M}^{+}\right)$and $214\left(\mathrm{M}-\mathrm{CH}_{3}\right)$ (Barbalas and Garland 1991$)$. The mass spectrum was recorded for mass range $40-600 \mathrm{~m} / \mathrm{z}$ for 35 minutes.

Water samples were filtered through cellulose acetate filter with pore size of $0.45 \mu \mathrm{m}$ (Millipore HAWPO 4700 ) and $500 \mathrm{ml}$ was treated with $150 \mathrm{~g} \mathrm{NaCl}$ and three drops of $1: 1$ aqueous $\mathrm{HCl}$. The solution was mixed with $3.5 \mathrm{ml}$ of dichloromethane in separating funnel. The organic phase was dropped into a small glass tube and treated with anhydrous sodium sulphate. The organic phase was evaporated to dryness under nitrogen and dissolved in ethylacetate, which is injected for analysis. Bisphenol A dissolved in ethylacetae was used as standard. The work was done in GC-MS facility available in Confederation of Ayurvedic Reniassance Keralam Ltd., Trichur, Kerala, India.

\section{Collection of mosquito egg rafts}

Egg rafts of Culex.sp. of mosquitoes were collected by keeping 3 litres of water mixed with contents of two raw eggs of domestic fowl in buckets placed at damp corners of the College campus. Mosquitoes started laying eggs after 2-3 days, once foul smell emanated from the bucket of water sample and egg rafts were collected everyday in the morning.

\section{Identification of Culex at species level}

Identification of adult mosquitoes were done as Culex quinquefasciatus Say. by using the taxonomic key (Barruad 1934) and instars of larvae were identified (Tripathy and Dash 1988) after killing by heat killed method. Larvae were killed in hot water just below boiling point and put them in $70 \%$ ethanol, before mounting on a clean glass slide and observed under (10x) microscope (Leica,Germany).

\section{Rearing of C.quinquefasciatus larvae}

Collected egg rafts were transferred into enamelised metal pans $(20 \mathrm{~cm}$ diameter and $10 \mathrm{~cm}$ depth) containing of egg- water medium $(500 \mathrm{ml})$ and diluted to one litre with dechlorinated water. The rearing 
medium was changed every three days. The metal pan with developing larvae were kept in the insectarium (cage made of mosquito net and metal frame) for emergence of adults. Temperature of the insectarium ranged between 26 and $31^{\circ} \mathrm{C}$ and humidity was kept above $75 \%$ by keeping the floor wet.

\section{Mixing of BPA in water}

BPA was dissolved in ethanol in such a way that $50 \mu$ l of ethanol possessed different doses of BPA, starting from 1 to $50 \mathrm{mg}$. Fixed volume is added to one litre of rearing medium which resulted working dose of BPA starting from 1 to $50 \mathrm{ppm}$. Rearing medium applied with BPA was changed every three days.

\section{$\mathrm{LC}_{50}$ study of BPA}

As the length of each larval instar is approximately two days, 48 hours is considered as limit of activity/ toxicity. $\mathrm{LC}_{50}$ study was done in fourth instar larvae and it was calculated by Probit analysis.

\section{Study on span of lifecycle from egg to adult}

Newly laid egg rafts ( two, white coloured) were put on one litre larval rearing medium possessing $0,1,2$ and 4 ppm BPA. Duration in hours, required for hatching of eggs, larval- larval instars, pupation and eclosion to imago were recorded. The experiment was repeated six times and during the whole study period temperature ranged from $26-31^{\circ} \mathrm{C}$. The experiment was also done during the month of May (at the peak of summer in Kerala) in which the temperature ranged between 30 and $37^{\circ} \mathrm{C}$.

\section{SDS - PAGE Analysis}

SDS - PAGE of whole body homogenate was done by standard method (Laemmli 1970).All protein samples contained $100 \mu \mathrm{g}$ protein and electrophoresis was carried out using $12 \%$ Polyacrylamide gel, $\mathrm{pH}$ 8.8. Acrylamide : Bisacrylamide ratio was $30: 1$.

\section{In - gel tryptic digestion and Mass Spectroscopy - MALDI TOF / TOF}

Protein bands showing increase in band density and band volume (ten bands) between 66 and $97.4 \mathrm{kDa}$ corresponding to control and final instar larvae of C.quinquefasciatus developed in 1 and 2 ppm BPA as obtained in 2D SDS PAGE analysis were excised, destained, subjected to in - gel trypsin digestion and prepared for matrix - assisted laser desorption / ionization (MALDI) MS analysis. The MS analysis was done using Ultraflex III MALDI TOF/ TOF Mass spectrometer (Bruker Daltonik, Bremen, Germany). Spectra obtained were searched against Culex quinquefasciatus data base using the program MASCOT (Mascot Daemon; Matrix Science, Inc.,Boston, MA,USA). The search parameters were enzyme trypsin with one mixed cleavage, carbamidomethylation as fixed modification and oxidation of methionine as variable modification, 1.2 Da for peptide mass tolerance and 1.2 Da for fragment mass tolerance. Proteins identified were then analysed using the Uniprot data base ( http: //www.uniprot.org./).

\section{Estimation of $\mathbf{2 0}$-hydroxy ecdysone}


Estimation of 20HE was done in final instar larvae at every four hours, starting from $4^{\text {th }}$ hour of their emergence to pupation. Enzyme immunoassay of 20HE in the whole body homogenate was done by using the assay kit (Porcheron et al. 1989),Caymon Chemicals, (AO 5120\# 96 wells), France. Assay is based on competition between unlabelled $20 \mathrm{HE}$ and acetylcholine labelled $20 \mathrm{HE}$ for a limited amount of specific antiserum raised against $20 \mathrm{HE}$ in rabbit.

Five larvae, each of treatment and control were homogenized in $250 \mu$ l of ice cold methanol to extract $20 \mathrm{HE}$. The homogenate was centrifuged at $8000 \mathrm{~g}$ in refrigerated centrifuge and supernatant was

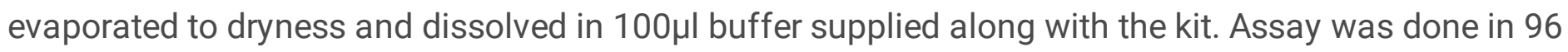
well microplate which was added with Ellman reagent, leading to chromogen formation. Absorbance of the chromogen was read by microplate reader at $405 \mathrm{~nm}$.

\section{Relative expression of genes by quantitative real time PCR}

Activity state of Ecdysone receptor A (ECRA) and Ecdysone regulated gene (E75A) in final instar larvae of control group and larvae developed in $1 \mathrm{ppm}$ BPA were done at the $30^{\text {th }}$ hour after the formation of the instar ( usually 50 to 52 hours is the length of the stadium). RNA was isolated by RNA isolation kit. Larval tissue $(100 \mathrm{mg}$ ) was homogenized in $1.0 \mathrm{ml}$ of Trizol reagent and shaken well with $200 \mu \mathrm{l}$ of chloroform for 15 minutes, centrifuged after three minutes at $14000 \mathrm{rpm}$. Aqueous layer was mixed with $500 \mu \mathrm{l}$ of isopropanol and centrifuged at $14000 \mathrm{rpm}$ for 15 minutes. Supernatant was discarded and the pellet was washed with $200 \mu \mathrm{l}$ of $75 \%$ ethanol. After centrifugation for 15 minutes at $14000 \mathrm{rpm}$, the pellet was dissolved in buffer. (Refrigerated centrifuge was used for all the above studies).

After assessing the purity and concentration of the extracted RNA, cDNA was prepared by Thermoscientific, Verso cDNA kit. Quantitative real time PCR was carried out using SYBR Green Master Mix (Applied Biosystem,Life Technologies). Normalisation was performed using primer specific for S7 ribosomal m-RNA. All the reactions were performed in triplicate and data were analysed. The primer sequences (Table S 1) used against each specific genes and after gene expression, values are normalized against S7 ribosomal protein gene (S7RP) as standard and relative expression level was calculated. The level of expression of two genes in control larvae is considered as background level or 1.0. Reproducibility of the experiments were verified by independent triplicate experiments

\section{Viability testing of adult mosquitoes developed in BPA}

Adult mosquitoes emerged from control and BPA treatments such as 1, 2 and $4 \mathrm{ppm}$ were tested for their sanguivorous behavior and egg laying performance. Pupae (120 numbers) developed in control and BPA groups were separately kept in mosquito cages for adult emergence. They were provided with $2 \%$ glucose by placing a $250 \mathrm{ml}$ beaker with the solution in which a filter paper roll was placed. They were provided with blood meal by allowing an albino rabbit which is partially immobilized by keeping in wire mesh and pinnae were shaved and kept overnight. After providing blood meal, fresh set up of glucose solution and a metal pan with one litre of larval rearing medium were kept in the cage. Humidity was maintained in the 
room by keeping the floor wet. Metal pan with larval rearing medium was observed for next six days for the presence of egg rafts.

\section{Recording the body weight of Pupa}

Pupae (50 number) were pooled together in clean water to free them off the dirts and gently blotted in tissue paper and weighed them together using an electronic balance (Shimadzu, Japan ). Weight of ten samples, each one with 50 pupae were recorded for each dose of BPA.

\section{Results And Discussion}

The present study reveals that the developmental stages of Culex quinquefasciatus can tolerate BPA up to a limited extent without causing lethal effects at a concentration of $5 \mathrm{ppm}, \mathrm{LD}_{50}$ of BPA in fourth instar larvae being $22.334 \mathrm{ppm}$ (Table S.2). Transgeneration study in $D$. ananassea also showed high tolerance towards BPA (Anuji, et al. 2018 ). The concentration of BPA in mosquito breeding sites of Thiruvananthapuram showed variation in relation to monsoon. During mosquito swarms after summer rain, these sites detected BPA at a range between 0.86 and $1.14 \mathrm{ppm}$ but during continuous rain it declined sharply to $9 \mathrm{ppb}$ (Table 1). Huge deposits of plastic wastes in water bodies and presence of BPA with high variation are detected in rivers, sewage and industrial effluents in studies carried out in China (Huang et al. 2011), United States of America (Kolpin et al.2002) and in one of these sites it ranges from 0.95 to $3.992 \mathrm{ppm}$ (Dong et al. 2009). Eventhough BPA is a pseudopersistant (Corrales et al. 2015), daily inputs of plastic wastes in mosquito breeding sites results in sustained release of this compound and hence BPA concentration of $1.0 \mathrm{ppm}$, found after summer rain is considered as environmentally relevant concentration .

The present study shows that BPA influences the development of $C$.quinquefasciatus, from egg to pupation (Table 2). Eggs deposited in water possessing 1 to 4 ppm BPA showed 14 to 18 hours of reduction in the duration for hatching of first instar larvae (Table 2), which indicated that BPA accelerated embryonic development of mosquitoes. No significant difference in the number of first instar larvae released from egg rafts between control and experimental groups. The number of first instar larvae hatched in the experimental group was $165.31 \pm 5.22$, from each egg raft and larval density was approximately $3.0 \mathrm{ml}$ per larva. The reduction in the duration of embryonic development was 40 and $50 \%$ when BPA concentration was 1 and 4 ppm respectively. However, there are no existing reports on the effect of BPA as an agonist on embryonic development of insects. BPA adversely affects the embryonic development in Daphnia magna, a freshwater crustacean (Mu Xueyan et al. 2005).

All larval instars of $C$.quinquefasciatus, from first instar to pupation showed 12 to $18 \mathrm{~h}$ of reduction in the duration of stadium, each one lasted for 52 to $56 \mathrm{~h}$, under ambient temperature of 26 to $31^{\circ} \mathrm{C}$ (Table 2). The total time taken for pupation was $260 \mathrm{~h}$ in controls. The larvae treated with $1 \mathrm{ppm}$ BPA took $182 \mathrm{~h}$, the decrease in duration being $43 \mathrm{~h}$ when compared to controls for pupation. The length of each stadium showed dose dependent reduction at increasing concentration of BPA viz; 1 to 4 ppm and at 4 ppm first 
instar larvae pupated barely within 164 hours. In almost all the studies in insects such as D.melanogaster (Alti and Ulnu 2012), D.ananassea (Anuji et al. 2018) and Musca domestica (Izumi et al. 2008) BPA delays in larval development. In C.quinquefasciatus, larval density is a major factor which governs the duration of larval development and overcrowding causes significant delay in the completion of lifecycle (Roberts and Kokkim 2010).

The results of the present study revealed that BPA had no effect on the duration required for the transformation of pupae to adults (Table 2). Under the experimental condition with atmosphere temperature varying between 26 and $31^{\circ} \mathrm{C}$, adults of the control group emerged on the $13^{\text {th }}$ day of egg laying, while treatment with 1 ppm BPA shortened life cycle from egg to adult emergence to 11 days i.e. , early compared to controls. The decrease in duration for adult emergence was found to be $72 \mathrm{~h}$ and $81 \mathrm{~h}$ when the concentration of BPA was increased to 2 and $4 \mathrm{ppm}$ respectively. The decrease in duration of larval period would affect feeding and cause a corresponding decrease in body weight of pupae (Table 3). However, at the environmentally relevant concentration of BPA at $1 \mathrm{ppm}$, such effects are not prominent.

Since temperature influences mosquito development (Ciota et al. 2014), the same experiment was conducted during the peak of summer at which the temperature ranged between 30 and $37^{\circ} \mathrm{C}$. Under this temperature, adult mosquitoes of the control group emerged 24 hours earlier, on $12^{\text {th }}$ day (Table 4), when compared to the controls emerging during rainy season with atmosphere temperature ranging between 26 and $31^{\circ} \mathrm{C}$.In larvae exposed to increasing concentration of BPA viz. 1, 2 and 4 ppm, the duration required for adult emergence was further reduced to 10,9 and 8.5 days respectively (Table 4 ). Elevation of temperature also resulted elevated activity of phenol oxidase (PO), its co-stimulator trypsin like serine protease (TLSP) and increased expression of phospholipase $A_{2}$ activating protein, as an adaptive response of to overcome temperature-induced stress (Gayathri and Evans 2018) and simultaneously, temperature and BPA act together with further reduction of life cycle span(Table 4). Identical response was also produced by the larvae in presence of BPA (Gayathri 2018). Elevation of PO and TLSP has important roles on immune responses (Murdok et al. 2012) and sclerotisation of cuticle which happens after moulting (Chu et al. 2017).

SDS-PAGE analysis of proteins extracted from BPA treated final instar C.quinquefasciatus larvae and their controls can be resolved into 15 bands with molecular weight ranging from 6.5 to $205 \mathrm{kDa}$. Larvae exposed to BPA showed increase in band volume and band width between $66-97.4$ kDa.(Fig. 1). New bands or disappearance of existing bands were not observed. Exposure of C.quinquefasciatus to ambient temperatures of $35^{\circ} \mathrm{C}$ to 10 or $15^{\circ} \mathrm{C}$ below or $5^{\circ} \mathrm{C}$ above the temperature also resulted identical changes in the protein profile in electropherogram (Gayathri and Evans 2018). MALDI - TOF /TOF analysis of the excised ten protein bands between $66-97.4 \mathrm{kDa}$ from both control and larvae developed in BPA revealed that first eight bands are importin sub unit alpha and set domain proteins in control and test. Bands of 9 and 10 were identified as putative uncharacterized protein and Phospholipase A2 activating protein respectively(Table 5). Exposure of C.quinquefasciatus larvae to hypothermia or 
hyperthermia also resulted expression of Phospholipase A2 activating protein and putative uncharacterized protein (Gayathri and Evans 2018 ).Identical physiological response exhibited by C.quinquefasciatus larvae reared in the presence of a xenoestrogen, which is actually a growth enhancer to this species and under exposure to extremes of temperature are interesting because both these agents have profound influence on the development of this poikilotherm. In the present study, it was found that BPA treated $C$. quinquefasciatus, maintained at temperature ranging between $26-31^{\circ} \mathrm{C}$ completed life cycle within 11 days compared to 13 days required for controls. This was further reduced for 10 days, while there was an elevation of temperature by $6^{\circ} \mathrm{C}\left(30-37^{\circ} \mathrm{C}\right)$. In Spodoptera exigua , Phospholipase A2 plays crucial role in insect immunity and larval growth (Youngjin et al. 2015). BPA induced expression of Phospholipase A2 in C.quinquefasciatus larvae might have played a significant role in inducing rapid development.

Studies in various species of arthropods have shown that BPA has adversely affects or delays larval development, while larvae were allowed to develop in presence of this compound (Watts et al. 2003; Alti and Ulnu 2012; Anuji et al. 2018; Mu Xueyan et al.2005; Izumi, et al. 2008), due to anti ecdysteroid activity of the chemical (Mu Xueyan et al.2005; Izumi et al. 2008). In house fly larvae, anti ecdysteroid activity of BPA appears to be mediated through excess synthesis of juvenile hormone II and III (Izumi et al. 2008) and in water flea it is found to be the result of enhanced activity of crustacean juvenile hormone methyl farnesoate ( Mu Xueyan, et al.2005). The present observation in C. quinquefasciatus larvae was distinct from other reports in that BPA had significantly shortened the stadium in all four larval instars and the compound did not cause any reduced availability or synthesis of endogenous ecdysone or any endocrine disruptor. Eventhough BPA caused endocrine disruption in many insect larvae, it did not exhibit any ecdysteroid receptor antagonism ( Mu Xueyan, et al.2005).

Induction of moulting in insects coincides with a surge in the release of 20-hydroxy ecdysone (20HE) prior to each larval moult and pupation. Periodic pulses of $20 \mathrm{HE}$ and juvenile hormone orchestrates the timing of moulting (Zhu and Norigea 2016). In C.quinquefasciatus, larval-pupal stadium having a total duration of 50-52 hours is characterized by three surges of 20-HE secretion (Fig. 2). The first surge of 20-HE occurred as the larvae passed one third of the stadium i.e. after $20 \mathrm{~h}$, producing a prominent peak. Increase in the titre of 20-HE continued and reached a second peak around two third of the stadium, which is followed by a third spike after 8 or $10 \mathrm{~h}$. Under the environmental temperature of 26 to $31^{\circ} \mathrm{C}$, the three peaks occurred approximately at 24,32 and $44 \mathrm{~h}$ leading to pupation after a lapse of $8 \mathrm{~h}$ (Fig.2). Larval-pupal stadium of Aedes aegypti also includes three peaks of 20-HE (Margam et al. 2006). It was found in the study that in $C$. quinquefasciatus, final instar larvae treated with BPA, the 20-HE peaks were advanced by 8-10h when compared with controls which culminated into pupation earlier by 10 hours (Table 2 and Fig. 2). This is shown to be a dose- dependent effect. The duration of larval instars too decreases with increasing doses of BPA. It is well known that moulting hormone functions as a key temporal signal in directing moulting and development (Zhu and Norigea 2016; Denlinger 2002) and hence early pupation in the presence of BPA could be the effect of early appearance of 20-HE peaks. 
Quantitative RT-PCR study on Ecdysone receptor A (EcRA) and Ecdy sone inducible gene E75A of final instar larvae of $C$. quinquefasciatus in presence of 1ppm BPA showed contrasting difference on their expression profiles (Fig.3). The relative EcRA and E75A mRNA showed double- fold elevation in BPA treated larvae, compared to controls during the two third of larval-pupal stadium(Fig. 4). Ecdysteroids in concert with EcR complex play important role in regulating reproduction and development in insects (Kumar et al.2002). In Chironomus tentans, increased EcRA expression occurs in response to 20-HE (Rouch et al. 1988). Larvae of C.riparius exposed to BPA also results in increased level of m-RNA of EcRA (Planello et al. 2008 ). During larval-pupal transition in Drosophila, activation of EcR/USP and E75A are under the direct control of 20-HE (Johnston 2011) and ecdysteroid induced E75A expression defines a feed forward pathway that amplifies or maintains the ecdysteroid titre during larval-pupal development ensuring proper temporal progression through lifecycle (Bialecki et al.2002). The present study indicates that BPA induced early peaks of 20-HE may have modulatory effects on EcRA and E75A through feed forward mechanism which inturn leads to shortened larval-larval and larval-pupal stadia, and thus the span of the life cycle as a whole.

The span of lifecycle and number of instars in holometabolous insects are genetically programmed. Being a poikilotherm, in mosquitoes lifecycle shortens as temperature increases (Ciota et al. 2014). This is further reduced by 60 or $80 \mathrm{~h}$ subsequent to treatment with BPA. The present study reveals that BPA acts as a developmental agonist in C.quinquefasciatus. Exogenous compounds such as fennoxycarb (Dedos et al. 2001 ), phytoecdysones such as 22-hydroxy cholesterol and 25-hydroxy cholesterol which are converted into 20-HE by the prothoracic gland of larvae (Warren et al. 2001 ) and anti JH compound fluoromevalonate (Farag and Varjas, 1983) are also developmental agonists in various holometabolous insects. These compounds cause precocious metamorphosis and adults thus formed are often nonviable and malformed (Warren et al. 2001; Farag and Varjas 1983 ). It was found in this study that, in C.quinquefasciatus, exposure of larvae to environmentally relevant concentration of BPA(1 ppm) caused significant reduction in the duration of larval period, while preserving all the larval instars. Though a significant reduction in pupal weight was observed, the duration of pupal period was same as in controls. The adults emerged appeared normal, fully viable and did not exhibit any significant difference with respect to sanguivory and fecundity (Table 6). Higher concentrations of 2 and $4 \mathrm{ppm}$ caused significant reduction in sanguivory and fecundity of adults. A similar observation is noticed in C.quinquefasciatus adults when larvae were maintained under conditions of overcrowding (Roberts and Kokkim 2010).

Accumulation of plastic wastes in sewages not only created stagnation and subsequent mosquito breeding but also facilitated a favourable environment which aggravated mosquito menace through shortening the lifecycle span. Plastic waste management itself can act as a vector control strategy through which release of mosquito developmental agonist in the ecosystem can be minimized.

\section{Declarations}

\section{Acknowledgements:}


Authors thank University Grants Commission, India for sanctioning research grant through Faculty Development Programme and Kerala State Council for Science, Technology and Environment for infrastructure development of Research Laboratory of Zoology Department, University College, Kerala, India.

\section{Consent for Publication}

The manuscript does not contain any individual's personal details and hence it is stated as " Not applicable".

\section{Consent to Participate}

The study reported in this paper did not incorporate any results of the observation involving human participants and hence it is stated as "Not applicable".

\section{Availabilty of Data materials}

All data generated or analysed during this study are available in this submitted article and its supplementary files.

Evans D.A

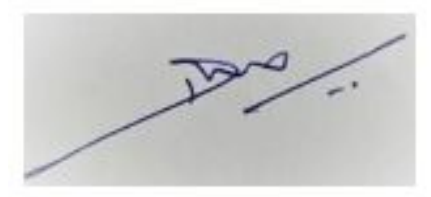

Corresponding author

\section{Ethics of Approval (Not applicable)}

a. The results incorporated in this paper did not include any information made on humans or on higher animals.

b. Individual person's data is not incorporated in this

All data incorporated in the paper is based on observations made on Culex quinquefasciatus.

\section{Competing Interests}

Both authors have no competing interests with any person, Institution or with any Organization.

\section{Funding :}

First author (Ms. Ayana Gayathri R.V., Assistant Professor of Zoology) was working under Faculty Improvement Programme of University Grants Commission (India) as Teacher Fellow for her Doctoral 
work, funded by UGC, India.

Infrastructure development of the Corresponding author's laboratory was supported by Kerala State Council for Science, Technology and Environment , Govt. of Kerala, India.

Both organizations (UGC and KSCSTE) are properly acknowledged in this paper.

\section{Author's contribution}

Results incorporated in the paper are a portion of the Ph. D thesis of Dr. Ayana Gayathri, R.V., who has done her doctoral work under the guidance and supervision of Dr. Evans, D. A., Associate Professor of Zoology. Contribution of the first author in this paper is $50 \%$ and corresponding author is $50 \%$.

All the information given above are true to the best of our knowledge.

On behalf of both authors

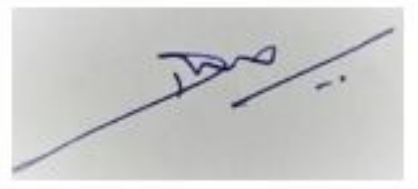

Dr. D.A. Evans

\section{References}

1. Alti E, Ulnu H (2012) Developmental and reproductive effects of bisphenol a in Drosophila melanogaster, Hacettepe J Biol Chem, 40: 61-68 .

2. Anuji TK, Shabithraj K, Sunny F, Evans DA ( 2018) Transgenerational effect of bisphenol a on phenotypic characters of Antennae in Drosophila ananassae (Doleschall). J Entomol Res, 42: 517523. doi : 10.5958/0974-4576.2018.00087.7.

3. Barbalas MP, Garland WA (1991) A computer programme for the deconvolution of mass spectral peak abundance data from experiments using stable isotopes, Journal of Pharmaceutical Sciences, 80: 911-916. doi : 10. 5958/ 0974-4576. 2018.0087.7.

4. Barraud PJ (1934) Diptera-Family Culicidae, Tribes: Megharhini and Culicini, In: Fauna of British India including Ceylon and Burma. Vol.5, R.B.S.Semel (Ed.) Taylor and Francis, London pp. 420-425 .

5. Bialecki M, Shilton A, Fichtenberg C, Segraves WA, Thummel CS (2002) Loss of ecdysteroid-inducible E75A orphan nuclear receptor uncouples molting from metamorphosis in Drosophila, Dev Cell, 3 : 209-220 . doi.org/ 10.1016/s1534-5807(02) 00204-6.

6. Biggers WJ, Laufer H (2004) Identification of Juvenile hormone active alkyl phenols in the lobster Hormarus americanas and in marine sediments, Biol Bull, 206: 13-24 . doi / 10. 2307/ 1543194. journals.uchicago. edu. 
7. Chu Y, Hong F, Liu Q, An C, (2017) Serine protease SP105 activates prophenoloxidase in Asian corn borer melanisation and is regulated by serpin-3. Sci Rep.7: 45256 . doi : org / 10. 1038/ srep 45256.

8. Ciota AT, Matacchiero AM, Kilpatric AM, Kramer LD (2014) The effect of temperature on the life history traits of Culex mosquitoes, J Med Entomol, 51: 55-62 . doi: 10. 1603/ me 13003.

9. Corrales J, Kristofco LA, Steele WB, Yates BS, Breed CS, Williams ES, Brooks BW (2015) Global assessment of Bisphenol $A$ in the environment: Review and analysis of its occurrence and Bioaccumulation, Dose- Response, 13 : 155932815598308. doi: 10.1177/ 155932815598308.

10. Dedos SG, Fugo H (2001) Acceleration of pupal - adult development by Fenoxycarb in the silk worm Bombyx mori, Zool Sci, 18: 771-777. doi. org / 10. 2108 /zsj. 18.771.

11. Denlinger DL (2002) Regulation of diapause. Annu Rev Entomol, 47: 93-122. doi : 10. 1146/ annurev.ento.47. 091201. 145137.

12. Dong J, Li XL, Luan T.G, Zou SC, Lin L (2009) Phenol pollution in the sediments of Pearl river estuary area and its potential risk assessment to the eco-security, J Saf Environ, 9: 113-116.

13. Fabbri R, Montagna M , Balbi T, Raffo E, Palumbo F, Canesi L (2014) Adaptation of the bivalve embryotoxicity assay for high through put screening of emerging contaminants in Mytilus galloprovincialis, Mar Environ Res, 99:1-8 . doi. 10. 1016/ j.marenvres. 2014. 05.007.

14. Farag Al, Varjas $L$ (1983) Precocious metamorphosis and moulting deficiencies induced by an antiJH compound, FMEV in the fall web worm Hyphantria cunea, Entomol Exp Appl, 34: 55-70 . doi. org/ 10.1111/ j.1570 - 7458. 1983.tb.0329.1.x.

15. Gayathri RVA, Evans DA (2018) Culex quinqnefasciatus Say larva adapts to temperature shock through changes in protein turn over and aminoacid catabolism, J Therm Biol, 74: 149- 159 .doi.org/ 10.1016 /j.therbio. 2018.03.016.

16. Gayathri RVA (2018. "Physiological response of Culex quinquefasciatus larvae to selected stressors", Ph.D. thesis, University of Kerala, India .

17. Huang YQ, Wong CKC, Zheng JS, Bouwman AK, Barra R, Wahlstrom B, Neretin L, Wong MH (2011) Bisphenol A (BPA) in China: a review on sources, environmental levels and potential human health impacts, Environ Int, 42: 91-99 . doi.10.1016/jenvnt.2011.04.010.

18. Izumi N, Yanagibori R, Shigeno S, Sajiki J(2008) Effects of bisphenol a on the development, growth and sex ratio of house fly Musca domestica, Environ Toxicol Chem, 27: 1343-1353 . doi.10.1897/07218.

19. Johnston DM, Sedkov Y, Petruk S, Riley KM, Fujioka M, Jaynes JB., Mazo, A (2011) Ecdysone and NO mediated gene regulation by competing EcR/USP and E75A nuclear receptor during Drosophila development, Mol Cell, 44: 51-61 . doi. 10.1016/ j.molcel.2011.07.033.

20. Kolpin DW, Furlong ET, Meyer MT, Thurman EM, Zaugg SD, Barber LB, Buxton HT (2002) Pharmaceuticals, hormones and other organic wastewater contaminants in US streams, 1999-2000: a national reconnaissance, Environ Sci Technol, 36: 1202-1211 . doi.10.1021/es 011055j.

21. Kumar MB, Fugimoto T, Potter DW, Deng Q, Palli SR (2002) A single potent modulation is EcR leads to increased ligand specificity: Implication is gene switch applications. Proc Natl Acad Sci USA, 99: 
14710-14715.

22. Laemmli UK ( 1970) Cleavage of structural proteins during the assembly of the head of bacteriophage T4. Nature, 227: 680-685 . doi.org/ 10.1038/227680ao.

23. Margam MV, Gelman DB, Palli SR (2006) Ecdysteroid titers and developmental expression of ecdysteroid regulated genes during metamorphosis of yellow fever mosquito Aedes aegypti, (DipteraCulicidae), J Insect Physiol, 52: 558-568 . doi. 10. 1016/ j.insphys.2006.02.03.

24. Mu X, Rider CV, Hwang GS, Hoy H, LeBlanc GA (2005) Covert signal disruption : anti-ecdysteroid activity of bisphenol a involves cross talk between signaling pathways, Environ Toxicol Chem, 24:146-152 . doi.org/10.1897/04 - 063R.1.

25. Murdock CC, Paaijmans KP, Bell AS, King JG, Hillyer JF, Read AF, Thomas MB (2012) Complex effects of temperature on mosquito immune function. Proc R Soc Lond Biol, 279: 3357-3366. doi.10. 1098/rspb 2012.0638.

26. Park Y, Kumar S, Kanumuri R, Stanley D, Kim Y (2015) A novel Calcium-independent cellular PLA2 acts in insect immunity and larval growth, Insect Biochem Mol Biol, 66: 13-23 . doi.10. 1016/ j.ibmb.2015. 09. 012.

27. Porcheron P, Moriniere M, Grassi J, Pradelles P (1989) Development of enzyme immunoassay for ecdysteroids using acetyl choline esterase as label. Insect Biochem, 19: 117-122 . doi.org/ 10.1016/ 0020 - 1790 (89) 90081-4.

28. Planello R, Martinez-Guitarte JL, Morcillo G (2008) Endocrine disruptor bisphenol A increases expression of $\mathrm{HSP}_{70}$ and ecdysone receptor genes in aquatic larvae of Chironomus riparius. Chemosphere, 71: 1870-1876 . doi.10.1016/j.chemosphere.200801.033.

29. Roberts D, Kokkim M (2010) Larval crowding effects on mosquito Culex quinquefasciatus, physical or chemical ? Entomol Exp Appl, 135: 271 - 275 .doi.org/10.1111/j.1570-7458.2010.00993.x.

30. Rouch P, Grebe M, Elke C, Spindler KD, Spindler BM (1998) Ecdysteroid receptor and ultraspiracle from Chironomus tentans (Insecta) are phospholipoproteins and are regulated differently by moulting hormone, Insect Biochem and Mol Biol, 27: 945-962. doi.10.1016/s0965-1748(98)00026-5.

31. Sumodan PK (2003) Potential rubber plantations as breeding source for Aedes albopictus in Kerala, India. Dengue Bull, 28: 39-43.

32. Sunilkumar S, Evans DA, Muthulakshmi K, Dilipkumar T, Pillai RH, Radhakrishnan Nair R, Francis Sunny (2018) Distrbution of Aedes aegypti and Aedes albopictus in different ecozones of Thiruvananthapuram city with special reference to Dengue viremia in humans, Entomon, 43: 223 230 . doi.33307/entamon. v43 14. 402.

33. Tripathy K, Dash AP (1988) Larvae of Culex sp. and Aedes sp. Morphology and identifying features In: Proceedings of the Symposium on Vectors and Vector Borne Diseases, Department of Zoology, University of Kerala, India .152-158.

34. Virk P, Al-Sarkan AAM, Elobeid MA (2014) Effect of bisphenol a on the levels of vitellogenin and metallothionein in adult male carp Cyprinus carpio L. Trop J Pharm Res, 13: 1107-1112 . doi.org/10.4314/tjpr.v13 i7.14. 
35. Warren JT, Bachmann JS, Dai J, Gilbert LI (1996) Differential incorporation of cholesterol and cholesterol derivatives into ecdysteroids by the ring gland and adult ovaries of Drosophila melanogaster, a putative explanation for I (3) ecd ${ }^{1}$ mutation, Insect Biochem Mol Biol, 26: 931-943 . doi.org/10.1016/s0965-1748(96) 00059-8.

36. Watts MM, Pascoe D, Carroll K (2003) Exposure to 17-a- ethinylestradiol and bisphenol a affects larval moulting and mouth parts structure of Chironomus riparius. Ecotoxicol Environ Saf, 54: 207215. doi.10.1016/s 0147-6513(02) 00029-5.

37. Yamamoto T, Yasuhara A (1999) Quantities of bisphenol A leached from plastic waste samples, Chemosphere, 38: 2569-2576 .doi.org/10.1016/s0045-6535(98) 00464-0.

38. Yang F-x, Xu Y, Wen S (2005) Endocrine disrupting effect of monophenol bisphenol A and pp' - DDE on Rana nigromaculata tadpoles, Bull Environ Contam Toxicol, 75: 1168-1175 . doi.10.1007/s 00128005-0872-2.

39. Yokota H, Tsuruda Y, Maeda M, Oshima Y, Tadokoro H, Nakazano A, Honjo T, Kobayashi K (2000) Effect of bisphenol a on the early life stage in Japanese medaka (Oryzias latipes), Environ Toxicol Chem, 19: 1925-1930 .doi.10.1002/etc.5620190730.

40. Youngjin P, Kumar S, Kanumuri R, Stanley D, Kim, Y (2015) A novel Calcium dependent cellular PLA2 acts in insect immunity and larval growth, Insect Biochemistry Mol Biol, 66: 13-23. doi.10.1016/j.ibmb.2015.09.012.

41. Zhu J, Norigea FG (2016) "The role of juvenile hormone in mosquito development". In : Advances in Insect Physiology (Progress in Mosquito Research, A. S. Raikhel, Ed. (Academic Press, Elsevier, 2016.), Vol.51, pp110-176. doi.10.1016/bs-aiip.2016.04.005.

\section{Tables}

Table $1 \mathrm{GC}$ - MS Analysis of Bisphenol A in water samples of mosquito breeding sites

\begin{tabular}{|lll|}
\hline Mosquito Breeding sites & Six days after summer rain & During Monsoon \\
\cline { 2 - 3 } & Amount in ppm & Amount in $\mathrm{ppb}$ \\
\hline 1 & 0.86 & 12 \\
\hline 2 & 1.14 & 16 \\
\hline 3 & 1.02 & 14 \\
\hline 4 & 1.01 & 09 \\
\hline
\end{tabular}

Table 2 Development of Culex quinqnefasciatus in Bisphenol A, under the environmental temperature of 26-31 ${ }^{\circ} \mathrm{C}$. 


\begin{tabular}{|c|c|c|c|c|c|}
\hline \multirow[t]{2}{*}{$\begin{array}{l}\text { Sl. } \\
\text { No. }\end{array}$} & \multirow[t]{2}{*}{ Life cycle stage } & \multicolumn{4}{|c|}{$\begin{array}{l}\text { Duration in hours for development in presence of } \\
\text { Bisphenol A (duration in days given in parenthesis) }\end{array}$} \\
\hline & & Control & $1 \mathrm{ppm}$ & $2 p p m$ & $4 p p m$ \\
\hline 1 & Hatching of egg & $35.5 \pm 2.2$ & $21.3 \pm 2.8$ & $19.4 \pm 3.0$ & $18.6 \pm 1.65$ \\
\hline 2 & First Instar & $56.5 \pm 3.1$ & $44.2 \pm 2.9$ & $40.2 \pm 3.0$ & $38.2 \pm 3.4$ \\
\hline 3 & Second Instar & $57.8 \pm 3.5$ & $43.1 \pm 2.3$ & $42.2 \pm 2.4$ & $40.3 \pm 2.1$ \\
\hline 4 & Third Instar & $58.5 \pm 4.2$ & $48.6 \pm 2.9$ & $47.6 \pm 2.1$ & $46.1 \pm 1.95$ \\
\hline 5 & Fourth Instar & $52.1 \pm 4.2$ & $45.6 \pm 2.6$ & $41.8 \pm 1.8$ & $39.3 \pm 1.6$ \\
\hline 6 & Egg to pupation & $\begin{array}{l}260.4 \pm 19.9 \\
(10.85 \pm 0.83)^{\star}\end{array}$ & $\begin{array}{l}202.8 \pm 8.02 \\
(8.45 \pm 0.33)\end{array}$ & $\begin{array}{l}191.2 \pm 7.7 \\
(7.96 \pm 0.32)\end{array}$ & $\begin{array}{l}182.5 \pm 8.22 \\
(7.60 \pm 0.34)\end{array}$ \\
\hline 7 & Pupal duration & $52.0 \pm 4.6$ & $49.2 \pm 3.62$ & $48.8 \pm 3.94$ & $48.5 \pm 3.87$ \\
\hline 8 & Duration of Egg to adult & $\begin{array}{l}312.4 \pm 12.36 \\
(13.01 \pm 0.52)^{\star}\end{array}$ & $\begin{array}{l}252.0 \pm 14.02 \\
(10.5 \pm 0.58)\end{array}$ & $\begin{array}{l}240.1 \pm 11.87 \\
(10.0 \pm 0.49)\end{array}$ & $\begin{array}{l}231.0 \pm 14.22 \\
(9.63 \pm 0.59)\end{array}$ \\
\hline
\end{tabular}

Values are mean $+S E, \quad p<0.05, n=6$.

(All values except pupal life duration are significantly different from control)

*Values in Parentheses indicate duration in days.

Table 3 Body weight of Culex quinquefasciatus pupae developed in different concentration of BPA

\begin{tabular}{|llr|}
\hline Concentration of BPA(ppm) & \multicolumn{2}{l|}{ Body weight of 50 pupa $(\mathrm{mg})$} \\
\cline { 2 - 3 } & Range & Mean \pm SEM \\
\hline 0 & $110-121$ & $116.20 \pm 1.28$ \\
\hline 1 & $108-120$ & $112.40 \pm 1.71$ \\
\hline 4 & $98-112$ & $105.20 \pm 1.48$ \\
\hline
\end{tabular}

Values are mean + SEM, $n=10, p<0.05$,Body weight of pupae showed dose dependent decrease.

Table 4 Development of Culex quinquefasciatus in Bisphenol A under the environmental temperature of 30-370 C. 


\begin{tabular}{|c|c|c|c|c|c|}
\hline \multirow{2}{*}{$\begin{array}{l}\text { Sl. } \\
\text { No. }\end{array}$} & \multirow{2}{*}{$\begin{array}{l}\text { Life cycle stage } \\
\text { (hours) }\end{array}$} & \multicolumn{4}{|c|}{$\begin{array}{l}\text { Duration in hours for development in presence } \\
\text { of Bisphenol } A(\mathrm{ppm})\end{array}$} \\
\hline & & Control & 1 & 2 & 4 \\
\hline 1 & Hatching of egg & $\begin{array}{l}29.3+ \\
2.3\end{array}$ & $19.0+1.7$ & $\begin{array}{l}17.9+ \\
1.8\end{array}$ & $\begin{array}{l}16.4+ \\
1.70\end{array}$ \\
\hline 2 & First Instar & $\begin{array}{l}49.4+ \\
2.6\end{array}$ & $39.0+2.6$ & $\begin{array}{l}36.5+ \\
2.2\end{array}$ & $\begin{array}{l}35.6+ \\
2.4\end{array}$ \\
\hline 3 & Second Instar & $\begin{array}{l}50.50+ \\
3.0\end{array}$ & $39.6+2.9$ & $\begin{array}{l}35.4+ \\
3.1\end{array}$ & $\begin{array}{l}34.7+ \\
2.9\end{array}$ \\
\hline 4 & Third Instar & $\begin{array}{l}51.6+ \\
2.8\end{array}$ & $44.6+3.01$ & $\begin{array}{l}41.7+ \\
3.2\end{array}$ & $\begin{array}{l}40.8+ \\
2.5\end{array}$ \\
\hline 5 & Fourth Instar & $\begin{array}{l}48.7+ \\
2.4\end{array}$ & $38.9+3.2$ & $\begin{array}{l}35.1+ \\
2.4\end{array}$ & $\begin{array}{l}34.9+ \\
3.0\end{array}$ \\
\hline 6 & Duration of Egg to pupation(Hours) & $\begin{array}{l}229.5 \\
+13.1\end{array}$ & $181.1+13.41$ & $\begin{array}{l}166.6+ \\
12.7\end{array}$ & $\begin{array}{l}163.4+ \\
12.5\end{array}$ \\
\hline 7 & $\begin{array}{l}\text { Duration of Egg to pupa (Days ) } \\
0 \quad 0 \text { (Days) }\end{array}$ & $\begin{array}{l}9.5+ \\
0.54\end{array}$ & $7.5+0.56$ & $\begin{array}{l}6.9+ \\
0.52\end{array}$ & $\begin{array}{l}6.8+ \\
0.52\end{array}$ \\
\hline 8 & Eclosion & $\begin{array}{l}48.5+ \\
2.10\end{array}$ & $46.8+3.10$ & $\begin{array}{l}46.1+ \\
2.4\end{array}$ & $\begin{array}{l}46.0+ \\
2.3\end{array}$ \\
\hline 9 & Duration of Egg to adult (Hours) & $\begin{array}{l}278.0 \\
+15.2\end{array}$ & $\begin{array}{l}227.9+ \\
16.51\end{array}$ & $\begin{array}{l}212.7+ \\
15.1\end{array}$ & $\begin{array}{l}209.4+ \\
14.8\end{array}$ \\
\hline 10 & Duration of Egg to adult (Days) & $\begin{array}{l}11.58+ \\
0.6\end{array}$ & $9.49+0.68$ & $\begin{array}{l}8.86+ \\
0.62\end{array}$ & $\begin{array}{l}8.68+ \\
0.61\end{array}$ \\
\hline
\end{tabular}

Values are mean $+\mathrm{SE}, \mathrm{p}<0.05, \mathrm{n}=6$.

(All values except pupal life duration are significantly different from control)

Table 5. Proteins identified in C. quinquefasciatus larvae reared in 1 and 2ppm BPA

\begin{tabular}{|lllcccc|}
\hline $\begin{array}{l}\text { Band } \\
\text { No. }\end{array}$ & $\begin{array}{l}\text { Accession } \\
\text { no. }\end{array}$ & Protein name & Observed & $\operatorname{Mr}($ expt) & $\operatorname{Mr}($ calc) & $\begin{array}{l}\text { Mascot } \\
\text { Score }\end{array}$ \\
\hline 1 & $\begin{array}{l}\text { BOWH10 } \\
\text { CULQU }\end{array}$ & $\begin{array}{l}\text { Putative uncharacterized } \\
\text { protein }\end{array}$ & 1651.63 & 1652.87 & 1651.81 & 53 \\
\hline 2 & $\begin{array}{l}\text { BOW037 } \\
\text { CULQU }\end{array}$ & $\begin{array}{l}\text { Phospholipase A2- } \\
\text { activating protein }\end{array}$ & 1497.48 & 1495.72 & 1495.62 & 53 \\
\hline
\end{tabular}

Mr- relative molecular mass.

Ion score is $-10^{\star} \log (P)$, where $P$ is the probability that the observed match is a random event. Individual ion scores $>31$ indicate identity or extensive homology $(P<0.05)$. 
Table 6 Sanquivory and fecundity of C.quinquefasciatus developed in BPA

\begin{tabular}{|c|c|c|c|c|c|}
\hline $\begin{array}{l}\text { Doses } \\
\text { of BPA } \\
\text { (ppm) }\end{array}$ & $\begin{array}{l}\text { Number } \\
\text { of adults } \\
\text { hatched.* }\end{array}$ & $\begin{array}{l}\text { Number of } \\
\text { female } \\
\text { mosquitoes }\end{array}$ & $\begin{array}{l}\text { Number of } \\
\text { blood fed } \\
\text { mosquitoes }\end{array}$ & $\begin{array}{l}\text { Number of egg rafts } \\
\text { observed within six days } \\
\text { of blood meal }\end{array}$ & $\begin{array}{l}\text { Number of larvae } \\
\text { hatched from an } \\
\text { egg raft }\end{array}$ \\
\hline Control & $\begin{array}{l}118.50 \pm \\
1.04\end{array}$ & $\begin{array}{l}60.00 \pm \\
3.94\end{array}$ & $32.16 \pm 3.20$ & $21.16 \pm 2.13$ & $163.83 \pm 7.35$ \\
\hline 1 & $\begin{array}{l}117.51 \pm \\
1.52\end{array}$ & $\begin{array}{l}61.88 \pm \\
3.88\end{array}$ & $31.83 \pm 3.32$ & $21.33 \pm 1.63$ & $162.50 \pm 7.34$ \\
\hline 2 & $\begin{array}{l}117.62 \pm \\
1.46\end{array}$ & $\begin{array}{l}60.17 \pm \\
4.83\end{array}$ & $26.33 \pm 2.00$ & $17.50 \pm 1.64$ & $135.83 \pm 6.51$ \\
\hline 3 & $\begin{array}{l}117.00 \pm \\
0.96\end{array}$ & $\begin{array}{l}59.33 \pm \\
4.71\end{array}$ & $\begin{array}{l}23.43 \pm \\
2.88\end{array}$ & $16.01 \pm 1.41$ & $100.50 \pm 7.31$ \\
\hline
\end{tabular}

* 120 pupae developed in control and different doses of BPA were allowed to develop as adult mosquitoes and were provided blood meal and allowed to lay eggs.

\section{Figures}




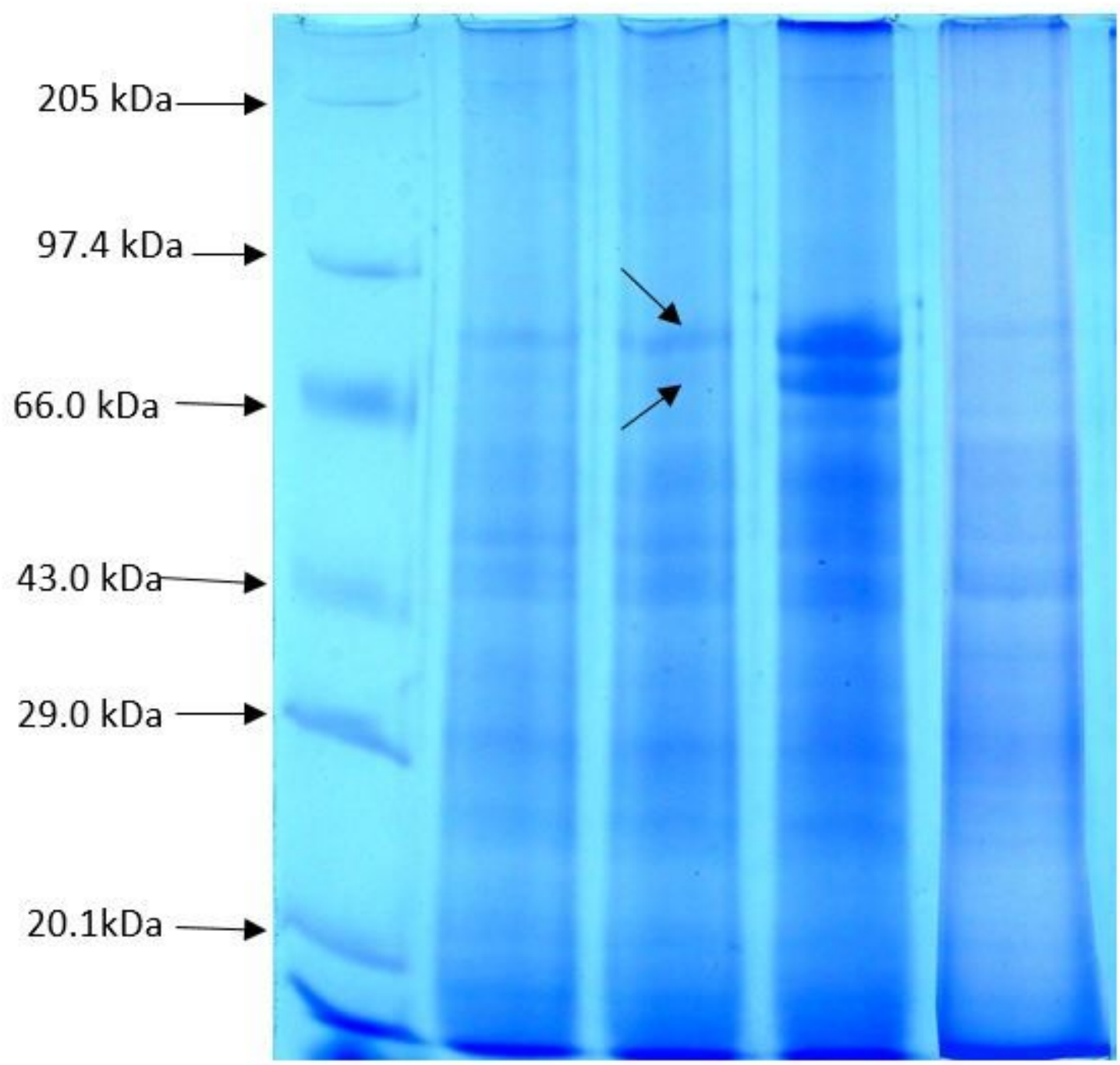

\section{Figure 1}

Electropherogram of fourth instar C.quinquefasciatus larvae reared in selected concentrations of BPA. Lane 1 : Marker, Lane 2 : Control larvae developed in temperature range of $26-310 \mathrm{C}$ Lanes 3 :Larvae developed in $1 \mathrm{ppm}$ attemperature range of $26-31$ 0C Lane 4 : Larvae developed in $2 \mathrm{ppm}$ at temperature range of $26-310 \mathrm{C}$ Lane 5 : Control larvae developed in temperature range of $30-370 \mathrm{C}$ 


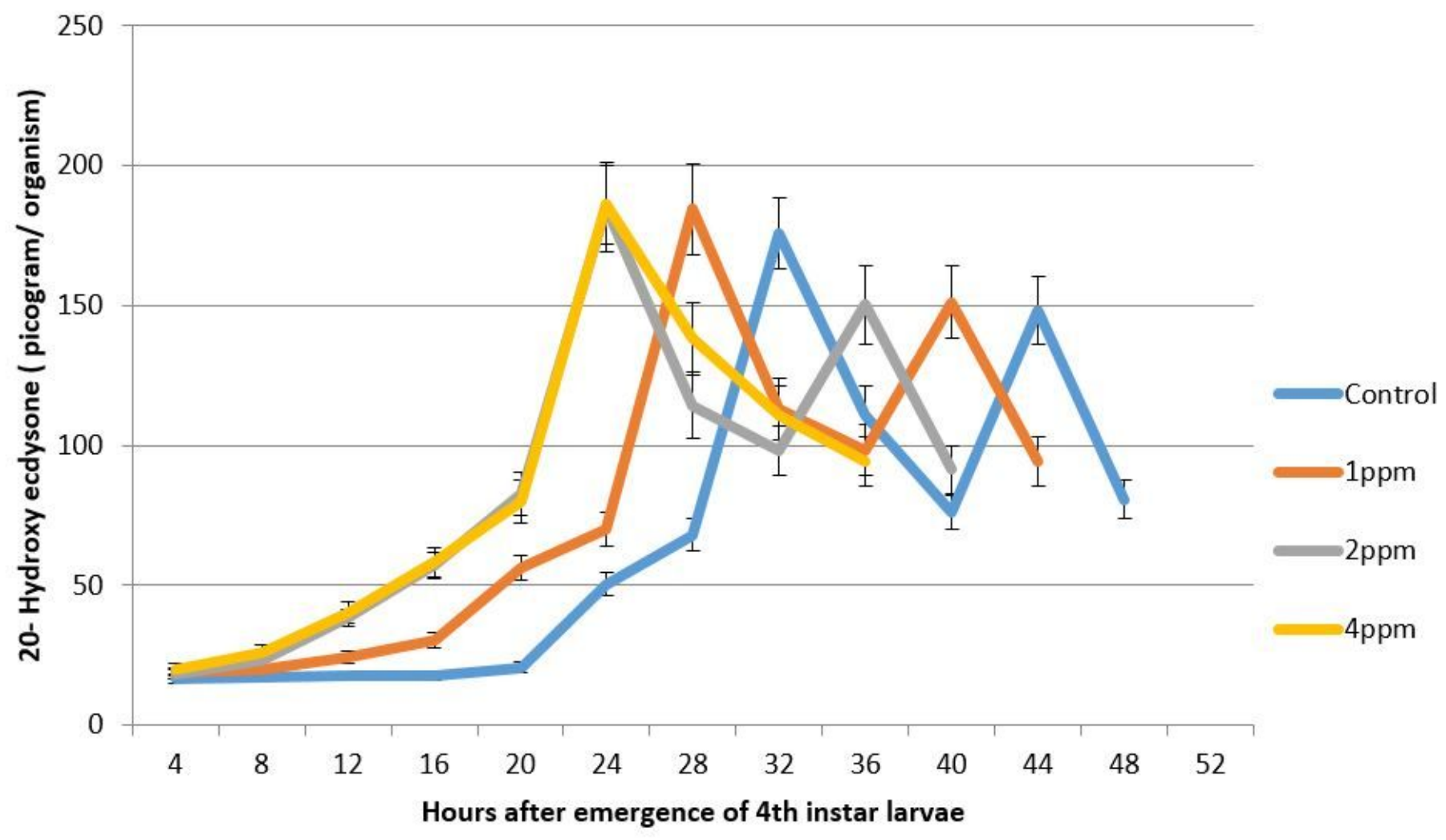

Figure 2

20- hydroxy ecdysone levels during larval - pupal transformation of C.quinquefasciatus developed in different doses of BPA. Values are mean $\pm S E M, p<0.05, n=6$ (Values are significantly different from control) 


\section{Control Test}

\section{Cq S7RP}

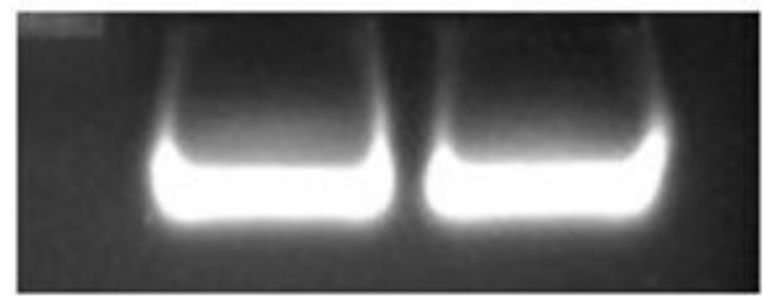

Cq EcRA

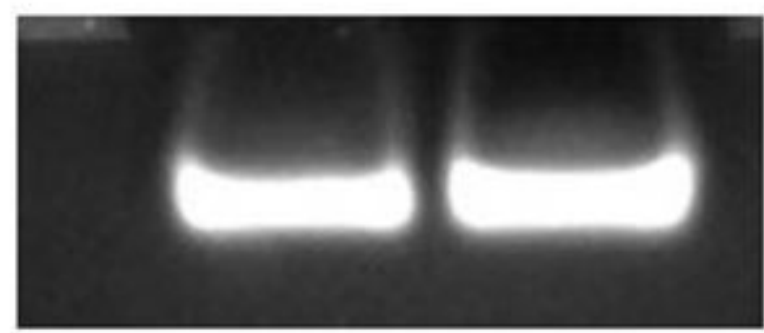

Cq E75A

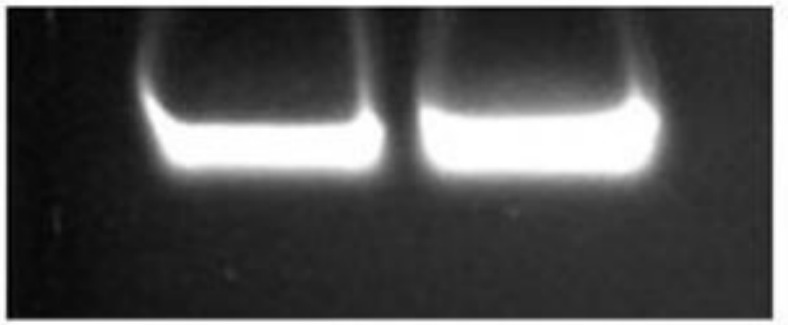

\section{Figure 3}

Amplified products of genes in final instar larvae of C.quinquefasciatus developed in 1 ppm BPA 1st row is S7RP normalising gene ; 2 nd row is EcRA, Ecdysone receptor A and 3rd row is E75A, Ecdysone regulated gene. 


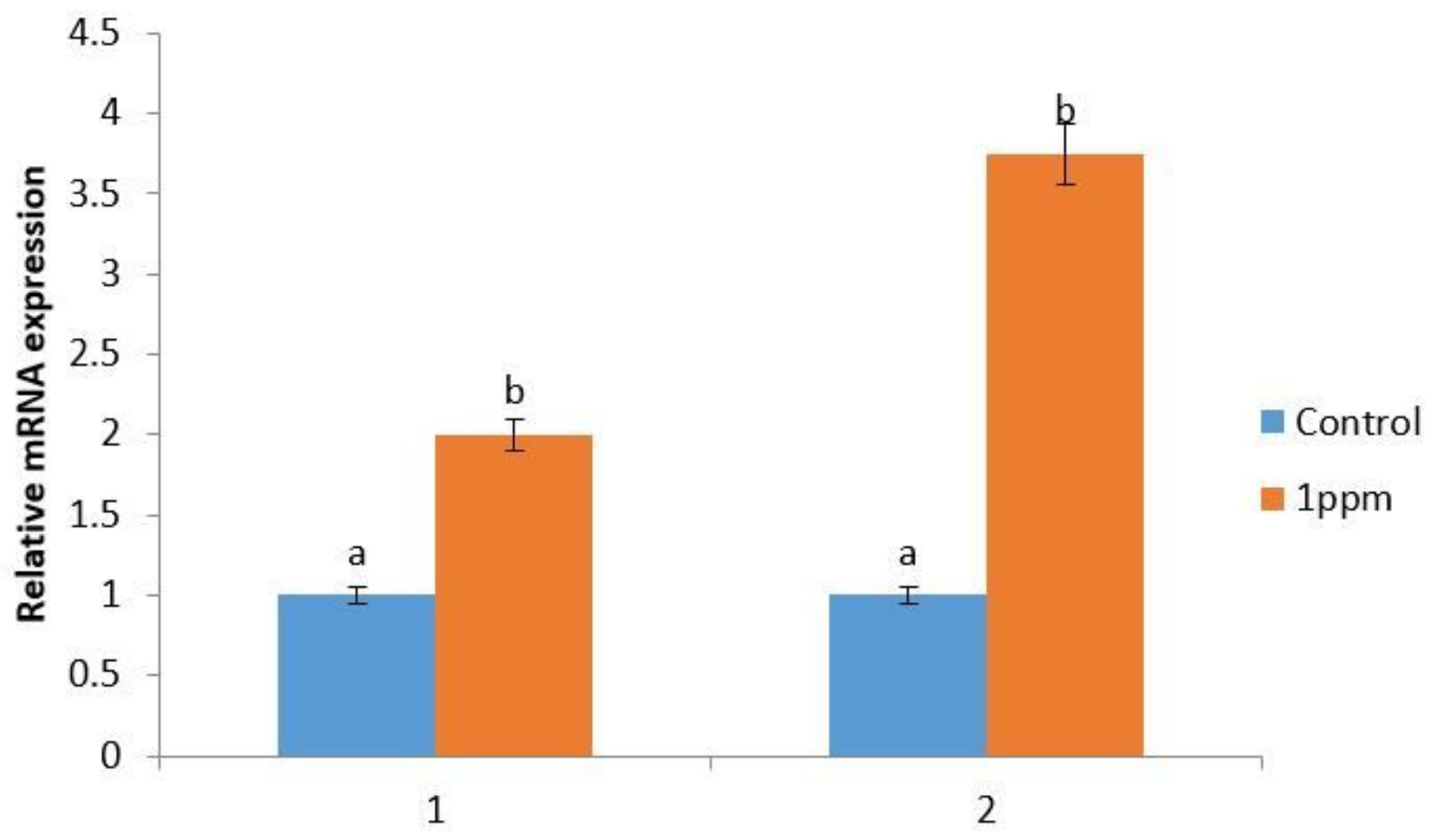

Figure 4

Expression of Ecdysone regulated genes, EcRA and E75A in final instar larvae of C. quinquefasciatus developed in 1 ppm BPA Values are Mean $(n=3) \pm$ S.E.M (Standard Error of Mean). Mean values of different superscript letters $(a, b)$ were significantly different $(p \leq 0.05)$.

\section{Supplementary Files}

This is a list of supplementary files associated with this preprint. Click to download.

- Listofsupplementarymaterials.docx 